\title{
ІННОВАЦІЙНІ АСПЕКТИ УДОСКОНАЛЕННЯ СИСТЕМИ МЕНЕДЖМЕНТУ ОРГАНІЗАЦИЙ У СУЧАСНИХ УМОВАХ
}

\begin{abstract}
Актуальність дослідження обумовлена необхідністю створення ефективної системи менеджменту для організації, яка забезпечить можливості виходу на новий рівень розвитку, що передбачає модернізацію організаційної структури управління та збільшення ії ефективності; зниження витрат; підвищення рівня безпеки послуг і продукції; випуск продукції із якістю, на яку очікує споживач, збільшення кількості кінцевих споживачів і займання позиції найкращого постачальника; збільшення обсягів збуту продукції та послуг; оперативне реагування на ринкові коливання; підвищення продуктивності; захист свосї торговельної марки і репутації.

Метою написання статті с розробка загальної системи менеджменту організації, виявлення суттсвих якісних характеристик ефективної системи менеджменту організації та різних інновацій, які дозволяють упроваджувати їй довгострокові стратегії і забезпечують конкурентоспроможність в цілому.
\end{abstract}

Методи дослідження - системний підхід, методи аналізу та синтезу, порівняння.

Проаналізовано підходи щодо змісту, структури та наповнення сучасних систем менеджменту організації. Розкрито специфіку й проаналізовано функціонування компанійрітейлерів і їх структурних одиниць. Виділено якісні результативні характеристики сучасної системи менеджменту організації, сформульовано визначення сучасної системи менеджменту організації (підприсмства). Запропоновано загальну схему системи менеджменту організації «вищого рівня» для забезпечення конкурентоспроможності та розвитку організації.

Сформульовано заходи із підвищення конкурентоспроможності та стратегічної стійкості компанії «АЛЛО», а саме: 1) врахування сезонних факторів попиту на товари; 2) упровадження нових ідей (соціальних інновацій) залучення кліснтів, які відрізняються від ідей компанійконкурентів; 3) упровадження в систему менеджменту більшої кількості мотиваційних програм для заохочення співробітників; 4) застосування інноваційних освітніх заходів програми лояльності клієнтів, що підвищують цінність послуг компанії як для індивідуумів, так і суспільства в цілому; 5) розширення асортименту магазинів для залучення нових кліснтів i підвищення прибутку.

Наукова новизна дослідження полягає у визначенні сучасних вимог споживачів до компаній-рітейлерів електронної техніки, обгрунтуванні розширення обсягу соціальних інновацій в умовах нестабільного зовнішнього середовища та активізації свроінтеграційних процесів в Україні, формулюванні суттсвих якісних характеристик ефективної системи менеджменту організації, трактуванні терміна «системи менеджменту організації» та розробці оптимальної загальної схеми функціонування системи менеджменту («вищого рівня») організації із урахуванням процесів створення та покращення.

Практична значущість дослідження полягає у створенні чіткої схеми реалізації системи менеджменту («вищого рівня») організації, яка реалізує функції розвитку, виконання, оцінки, підтримки для організації будь-якого типу, у тому числі й для компанії-рітейлера електронної техніки.

Подальшого дослідження потребують розробка нормативних документів за системою менеджменту організації в межах загальної схеми системи менеджменту («вищого рівня»), розробка різноманітних інновацій, які враховують регіональний аспект розміщення компанії, швидке впровадження позитивного досвіду міжнародних компаній-рітейлерів.

Ключові слова: система менеджменту організації; якісні характеристики ефективної системи менеджменту організації; конкурентоспроможність організації; розвиток організації.

(С) Джур О. Є., Шулякова А. С., 2016 


\author{
О. Е. Джур, А. С. Шулякова \\ Днепропетровский национальный университет имени Олеся Гончара, Украина
}

\title{
ИННОВАЦИОННЫЕ АСПЕКТЫ СОВЕРШЕНСТВОВАНИЯ СИСТЕМЫ МЕНЕДЖМЕНТА ОРГАНИЗАЦИЙ В СОВРЕМЕННЫХ УСЛОВИЯХ
}

Актуальность исследования обусловлена необходимостью создания эффективной системы менеджмента для организации, которая обеспечит возможности выхода на новый уровень развития, предусматривающей возможность модернизации организационной структуры управления и увеличения её эффективности; снижения затрат; повышение уровня безопасности услуг и продукции; выпуска продукции с качеством, которое ожидает потребитель, увеличение количества конечных потребителей и занятия позиции лучшего поставщика; увеличение объёмов сбыта продукции и услуг; оперативное реагирование на рыночные колебания; повышение производительности; защиту своей торговой марки и репутации.

Целью написания статьи является разработка общей системы менеджмента организации, выявление существенных качественных характеристик эффективной системы менеджмента организации и различных инноваций, которые позволяют ей внедрять долгосрочные стратегии и обеспечивают конкурентоспособность в целом.

Методы исследования - системный подход, методы анализа и синтеза, сравнения.

Проанализированы подходы к содержанию, структуре и наполнению современных систем менеджмента организации. Раскрыта специфика и проанализировано функционирование компаний-ритейлеров и их структурных единиц. Выделены качественные результативные характеристики современной системы менеджмента организации, сформулировано определение современной системы менеджмента организации (предприятия) и предложена общая схема системы менеджмента «высшего уровня» для обеспечения конкурентоспособности и развития организации.

Рекомендованы меры для повышения конкурентоспособности и стратегической устойчивости компании «АЛЛО», а именно: 1) учёт сезонных факторов спроса на товары; 2) внедрение новых идей (социальных инноваций) привлечения клиентов, которые отличаются от компаний-конкурентов; 3) внедрение в систему менеджмента большего количества мотивационных программ для поощрения сотрудников; 4) внедрение инновационных образовательных мероприятий программы лояльности клиентов, которые повышают ценность услуг компании как для индивидуумов, так и общества в целом; 5) расширение ассортимента магазинов для привлечения новых клиентов и повышения прибыли.

Научная новизна исследования заключается в определении современных требований потребителей касательно компаний-ритейлеров электронной техники, обосновании расширения объёма социальных инноваций в условиях нестабильной внешней среды и активизации евроинтеграционных процессов в Украине, формулировке существенных качественных характеристик эффективной системы менеджмента организации, трактовке термина «системы менеджмента организации» и разработке оптимальной общей схемы функционирования системы менеджмента («высшего уровня») организации с учётом процессов создания и улучшения.

Практическая значимость работы заключается в создании чёткой схемы реализации системы менеджмента («высшего уровня») организации, реализующей функции развития, исполнения, оценки, поддержки для организации любого типа, в том числе и для компанииритейлера электронной техники.

Дальнейшего исследования требуют разработка нормативных документов по системе менеджмента организации в рамках общей схемы системы менеджмента («высшего уровня») организации, разработке различного вида инноваций, учитывающих региональный аспект размещения компании, быстрого внедрения положительного опыта международных компаний данного типа.

Ключевые слова: система менеджмента организации; качественные характеристики эффективной системы менеджмента организации; конкурентоспособность организации; развитие организации. 


\author{
O. Y. Dzhur, A. S. Shuljakova \\ Oles Honchar Dnipropetrovsk National University, Ukraine
}

\title{
INNOVATIVE ASPECTS OF THE IMPROVEMENT IN THE SYSTEM OF MANAGEMENT OF ORGANIZATIONS IN MODERN CONDITIONS
}

The relevance of the research is predetermined by the necessity of creating an efficient management system for an organization, which will provide for the possibility of entering new level of development, which implies modernization of the organizational structure of the management and increase in its efficiency; cost reduction; increase in the level of safety of services and products; production of quality products, expected by a consumer; increase in the number of end-users and holding position of the best provider; increase in sales of products and services; prompt response to market changes; improvement of performance; protection of the brand and reputation.

The purpose of writing this article is the development of the overall management system of an organization, identification of major qualitative characteristics of an efficient system of the management of an organization and of various innovations that allow implementing its long-term strategy and ensuring its competitiveness in general.

Research methods are system approach, methods of analysis and synthesis, comparison.

The approaches to the essence, structure and the content of modern systems of management of an organization were analyzed. The specifics were discovered and the functioning of companies in retail and of their structural units was analyzed. Qualitative efficient characteristics of modern system of the management of organizations were identified, and the definition of a modern system of the management of an organization (an enterprise) was formulated. General structure of the system of the management of the organization of a "higher level" was proposed to ensure competitiveness and development of the organization.

The measures to enhance competitiveness and strategic stability of the company «ALLO» were formulated, namely: 1) taking into account seasonal factors in the demand for goods; 2) implementation of new ideas (social innovations) to attract customers, which differ from the ideas of the companies-competitors; 3) introduction of more motivational programs for the promotion of employees, into the system of management; 4) application of innovative educational measures in the programs of customer loyalty, which increase the value of the company's services for both individuals and society as a whole; 5) expanding the assortment in the stores to attract new customers and increase profits.

The scientific novelty of the research is in determining current requirements of consumers to the companies, retailers of electronic equipment; substantiating the expanding of social innovations under conditions of unstable external environment and growth in the European integration processes in Ukraine; formulating essential qualitative characteristics of an efficient system of an organization management; interpreting the term "management system of an organization" and developing optimal general operation structure of the overall management system ("higher level") of an organization with regard to the processes of creation and improvement.

The practical significance of the study is the creation of a clear-cut procedure of implementation of the management system ("higher level") of an organization that fulfills the functions of development, implementation, evaluation and support for an organization of any type, including the company in the electronic equipment retail sales.

Further research will require the design of regulation documentation for the system of management of an organization in the framework of general structure of management system ("higher level"), development of various innovations that take into account regional aspect of the company's location, rapid introduction of positive experience of international companies in retail sales.

Keywords: management system of an organization, qualitative characteristics of an efficient system of the management of an organization, competitiveness of an organization, development of an organization.

Вступ. Управління сучасною організацією (підприємством) вирізняється складністю виробничих, соціальних та економічних процесів, відповідальністю менеджменту за результати діяльності організації, використання та оборот значних матеріальних, фінансових, трудових ресурсів. Результати діяльності сучасних великих організацій впливають на їх становище на галузевому ринку; економіку 
країни; на мікрорівні через соціально-економічне становище працівників організації та їх сімей; зовнішнє оточення організації - підприємствапостачальники та інших бізнес-партнерів. Усе це в підсумку визначає майбутнє організації - ii стійкість, конкурентоспроможність, особливості розвитку та корисність для суспільства. Орієнтація сучасних організацій на довгострокову перспективу потребує забезпечення їх стратегічної стійкості й конкурентоспроможності, що проявляється в здатності організацій створювати інноваційні продукти, послуги та процеси як у внутрішньому, так і зовнішньому середовищі, що формує конкурентні переваги на ринку покупця в умовах нестійкого та динамічного бізнес-середовища.

Створення ефективної системи менеджменту для організації науковці й практики розглядають стосовно можливості виходу на новий рівень розвитку, який передбачає можливість модернізації організаційної структури управління та збільшення іï ефективності; зниження витрат; підвищення рівня безпеки послуг i продукції; випуск продукції належної (очікуваної) якості, збільшення кількості кінцевих споживачів і займання позиції найкращого постачальника; збільшення обсягів збуту продукції та послуг; оперативне реагування на ринкові коливання; підвищення продуктивності; захист своєї торговельної марки та репутації. Сучасна система менеджменту організацій включає набір таких підсистем, як фінансовий, інвестиційний, стратегічний, інформаційний, інноваційний менеджмент, маркетинг, управління проектами, ризик-менеджмент, екологічний менеджмент, менеджмент якості.

Актуальним питанням створення та застосування систем менеджменту, їх теоретичної і практичної ефективності було присвячено наукові праці К. Арджириса, С. П. Бараненко, В. Н. Буркова, Т. Бернса, В. А. Ірікова, А. Я. Кібанова, П. М. Сенге, Г. М. Сталкера, В. В. Шеметова та ін.

Доцільність подальшого дослідження особливостей створення ефективної системи менеджменту для компаній-рітейлерів (на прикладі компанії «АЛЛО»), які працюють із великою кількістю індивідуальних споживачів в умовах насиченого конкурентного ринку України, обумовлена необхідністю постійного удосконалення та врахування специфіки діяльності із урахуванням місії компанії, іiі основних цілей (оперативних, тактичних i стратегічних), організаційної структури, системи інформаційного забезпечення, правильного вибору ключових показників ефективності, фінансової стабільності.

Постановка завдання. Метою написання статті є розробка загальної системи менеджменту організації, виявлення суттєвих якісних характеристик ефективної системи менеджменту організації й різних інновацій, які дозволяють упроваджувати довгострокові стратегії та забезпечують конкурентоспроможність організації в цілому.

Результати. Вивчаючи питання стійкості сучасних підприємств у працях багатьох науковців, можна помітити, що іï розглядають як результат їх здатності створювати, розвивати та довгий час зберігати конкурентні переваги на ринку за умов прискореного розвитку науково-технічного прогресу, проблем із ресурсами та впливом на екологію. Конкурентоспроможність підприємства трактують як передумову для досягнення стійкості підприємства на основі потенціалу, що включає: 1) здатність об'єктивно оцінювати очікування цільових груп споживачів; 2) спроможність здійснювати виробництво, результати якого відповідають вимогам покупців щодо якості та ціни товару; 3) здатність ефективно проводити маркетингову політику; 4) можливість зниження витрат на фактори виробництва 
(сировину та матеріали, енергію, капітал, робочу силу тощо); 5) здатність до створення та утримання технологічної переваги над галузевими конкурентами (стосується виробництва, збуту, управління і т.д.); 6) застосування інновацій у плануванні, організації та здійсненні ефективної стратегії у сфері виробництва, управління активами, маркетингу; 7) формування та розвиток організаційної культури підприємства на високому виконавчому та виробничому рівнях [1-5]. Для вирішення проблеми конкурентоспроможності Комісія із питань продуктивності праці в промисловості Массачусетського технологічного інституту рекомендувала заходи, що сприятимуть підвищенню конкурентоспроможності, а саме: 1) приділяти менше уваги проектам, які приносять короткостроковий прибуток, i більше інвестувати коштів у науково-технічні дослідження і конструкторські розробки; 2) періодично переглядати корпоративну стратегію своєї компанії, включаючи в неї «реакцію» на зміни конкурентної ситуації на міжнародному рівні (передбачає збільшення інвестицій у персонал і обладнання із метою покращити виробничі можливості фірми); 3) створювати якісну продукцію на стадії конструкторських розробок, приділяти більше уваги модернізації процесу, а не зосереджуватися на впровадженні інновації в саму продукцію [6]. Можливість фірми бути конкурентоспроможною на ринку визначає ії̈ здатність адаптуватися та своєчасно ухвалювати рішення в системі менеджменту на основі отриманої інформації.

Р. А. Фатхутдінов, розкриваючи сутність побудови системи менеджменту соціально-економічних і виробничих об'єктів, визначає, що стандартна структура системи менеджменту включає: а) внутрішнє оточення (вхід, вихід, зовнішнє середовище та зворотний зв'язок); б) внутрішню структуру (підсистема наукового супроводження, цільова, забезпечувальна, керувальна та керівна підсистеми). Науковець відзначає, що система менеджменту - це «система досягнення конкурентоспроможності керованого об’єкта» (тут і далі переклад наш. Aвm.) [7, c.173].

Консалтингова компанія «Management Systems» під час опису свого унікального підходу наголошує, що він включає «справжню систему менеджменту: оцінку, планування, структуру, розвиток лідерства, продуктивність менеджменту та менеджмент культури. Кожен із цих інструментів (які також є продуктами) автономний, а також об'єднаний із інтегрованою системою менеджменту» [8].

Міжнародна організація стандартизації (ISO) розробила стандарти, що стосуються системи менеджменту, які охоплюють такі напрямки, як якість, безпека та надійність, загальний менеджмент, здоров'я і медицина, навколишнє середовище й енергія, промисловість, послуги, інформаційні технології. У свою чергу блок стандартів із назвою «Загальний менеджмент» містить 12 стандартів, які деталізують окремі сфери діяльності менеджменту підприємств. У своїх документах Міжнародна організація стандартизації визначає систему менеджменту як «набір взаємопов'язаних і взаємодіючих елементів організації для формування політики, цілей і процесів для досягнення цих цілей» [9]. У стандарті ISO 19600:2014, наприклад, визначено, що організація - це «особа або група осіб, які спільно функціонують із зобов'язаннями, повноваженнями та зв'язками для досягнення цілей» і пояснено, що «концепція організації включає, не обмежуючи одиничного торгівця, компанію, корпорацію, фірму, підприємство, орган влади, партнерство, добродійність чи інститут, або частину, або комбінацію 3 цього, зареєстроване воно чи ні, публічне або приватне» [Там само]. 
Проблеми впровадження систем менеджменту на підприємствах колишніх країн СРСР розглянуто в журналі «Стандарты и качество» [10].

Компанія «АЛЛО» на сьогоднішній день - один із найбільших рітейлерів ринку мобільних телефонів і портативної цифрової техніки. Місія компанії: 1) покращення якості життя клієнтів, співробітників, партнерів і суспільства загалом; 2) просування світових цифрових технологій у життя суспільства та бізнес-середовище; 3) упровадження інновацій, створення цінностей для кліснтів, партнерів, інвесторів і персоналу; 4) повага, розвиток і цінування кваліфікованих співробітників, спроможних досягати мети. Цінності компанії «АЛЛО» тісно взаємопов'язані з іiі місією. Головними цінностями є орієнтація на задоволення потреб своїх клієнтів, гарантія і надійність співпраці з партнерами та впровадження нових ідей у свою діяльність. Стратегія компанії - бути лідером в Україні серед роздрібних гравців і постачальників комунікаційних технологій, портативного аудіо/відео і сервісів через мережу телекомунікаційних магазинів, партнерських магазинів, оптової торговлі та мережі Інтернет. Компанія завжди прагне до ще більшого зміцнення та розширення спектра взаємовідносин 3 покупцями i партнерами в усіх напрямах діяльності, прагне першою просувати на ринку інноваційні продукти та новинки техніки, що відображено у ії баченні -«АЛЛО партнер у здійсненні Вашої мрії».

Компанія «АЛЛО» у своєму управлінні застосовує філіальну систему. Філіальна, або дивізіональна, система управління належить до практики корпоративного управління. Основою формування структури даного типу $\epsilon$ виділення у складі організації практично самостійних відділів, комплексів «дивізіонів» і надання їм оперативно-господарської самостійності в отриманні прибутку 3 центральним управлінням корпоративною стратегією, науковими дослідженнями, інвестиціями, персоналом та інших централізованих функцій.

Якщо діяльність компанії поширюється на декілька регіонів і потрібне застосування різних стратегій, то доцільно формувати дивізіонально-регіональну структуру. У разі великої кількості самостійних відділень різного профілю діяльності застосовують організаційні структури на основі стратегічних одиниць. У цьому випадку для координації їх роботи створюють спеціальні проміжні управлінські органи між відділеннями i вищим керівництвом. Такі органи очолюють заступники вищого керівництва організації, їм надають статус стратегічних одиниць бізнесу, які являють собою організаційні елементи компанії, що відповідають за вироблення ії стратегічних позицій в одній або декількох сферах діяльності. На них покладають відповідальність за вибір сфери діяльності, розробку конкурентоспроможної продукції і збутових стратегій. Як тільки номенклатуру продукції розроблено, відповідальність за реалізацію програми покладають на підрозділи поточної комерційної діяльності.

Переваги дивізіональної структури управління:

- наявність тісних зв'язків між виробництвом і споживачами;

- швидке реагування на зміни в зовнішньому середовищі;

- поліпшення координації діяльності в підрозділах;

- підвищення відповідальності відділень у питаннях максимізації прибутку і завоювання позицій на ринку.

Недоліки дивізіональної структури управління:

- зростання управлінського апарату;

- збільшення витрат на утримання апарату управління;

- дублювання функцій управління в різних підрозділах; 
- боротьба за ресурси між підрозділами.

Філіальна система в компанії «АЛЛО» дозволяє на нижчих ланках управління здійснювати ефективне управління та координацію діяльності співробітників для виконання спільної стратегії та досягнення поставлених цілей.

Завдяки розвиненій системі мотивації персоналу та чіткого оцінювання досягнутих результатів кожен співробітник має можливість реального кар'єрного зростання, навчання i розширення зон відповідальності. Постійний прояв активності і мотивувальні акції для персоналу торгової мережі від компанійпартнерів дають реальну можливість підвищення доходу за рахунок цінних призів і грошових бонусів.

Головними конкурентами «АЛЛО» на ринку мобільних телефонів і портативної цифрової техніки $є$ компанії «Цитрус», «Ельдорадо», «Фокстрот», «Комфі».

Для того щоб краще проаналізувати та виявити недоліки в системі менеджменту «АЛЛО», здійснимо SWOT-аналіз. SWOT-аналіз - один із основних інструментів стратегічного управління, що оцінює в комплексі внутрішні й зовнішні чинники, які впливають на розвиток компанії. Методика проведення SWOT-аналізу передбачає декілька етапів. На першому етапі визначимо переваги й недоліки компанії «АЛЛО» (табл. 1).

Таблиця 1

Загальна характеристика переваг і недоліків компанії «АЛЛО»

\begin{tabular}{|l|ll|}
\hline \multicolumn{1}{|c|}{ Потенційні внутрішні переваги } & \multicolumn{3}{|c|}{ Потенційні внутрішні недоліки } \\
\hline а) сильна позиція у специфічних ринкових & а) динамічна та агресивна конкуренція 3 & боку \\
сегментах, відомий лідер; & ключових конкурентів; & \\
б) сприяння зростанню чисельності цільових & б) постійна конкуренція з конкурентами- \\
груп споживачів чи іх лояльності; & нелегалами; \\
в) можливості захисту від конкурентів; & в) негнучка цінова політика, витратний метод \\
г) достатні фінансові ресурси; & установлення цін; \\
д) вищі за середні технологічні та інноваційні & г) недостатня ознайомленість споживачів із \\
навички; & придбаними ними послугами & \\
е) добре вивчений ринок, потреби покупців; & & \\
вища за середню рентабельність і прибутковість \\
та маркетингові навички
\end{tabular}

На другому етапі розглянемо і проаналізуємо ринок у цілому. Цей етап дозволяє оцінити ситуацію поза межами підприємства і зрозуміти потенційні можливості й загрози (табл. 2).

Таблиця 2

Загальні можливості та проблеми для компанії «АЛЛО»

\begin{tabular}{|c|c|}
\hline Потенційні зовнішні можливості & Потенційні зовнішні загрози \\
\hline $\begin{array}{l}\text { a) розвиток економіки країни; } \\
\text { б) євроінтеграція як основа збільшення } \\
\text { масштабів бізнесу; } \\
\text { в) соціально-політична стабільність; } \\
\text { г) стабільне та обгрунтоване законодавство; } \\
\text { д) обслуговування додаткових груп споживачів; } \\
\text { е) входження у нові ринки (сегменти); } \\
\text { є) розширення виробництва для задоволення } \\
\text { потреб споживачів; } \\
\text { ж) можливість руху в бік привабливіших } \\
\text { стратегічних груп; } \\
\text { з) самозаспокоєність ключових конкурентів; } \\
\text { и) швидке зростання ринку }\end{array}$ & $\begin{array}{l}\text { a) інфляція; } \\
\text { б) військові дії та соціально-політична } \\
\text { нестабільність у сусідніх країнах та інших } \\
\text { регіонах світу; } \\
\text { в) значна ймовірність появи нових } \\
\text { конкурентів (у т. ч. іноземних); } \\
\text { г) уповільнений темп зростання ринку; } \\
\text { д) проблеми під час укладання договорів із } \\
\text { постачальниками й споживачами; } \\
\text { е) негативні демографічні зміни }\end{array}$ \\
\hline
\end{tabular}


На третьому етапі порівняємо переваги і недоліки підприємства 3 можливостями і загрозами ринку. Для порівняння можливостей підприємства 3 умовами ринку і узагальнення результатів SWOT-аналізу застосуємо матрицю SWOT (табл. 3).

Таблиця 3

Узагальнення результатів SWOT-аналізу для компанії «АЛЛО»

\begin{tabular}{|c|c|c|}
\hline Категорія & Переваги & Недоліки \\
\hline Можливості & 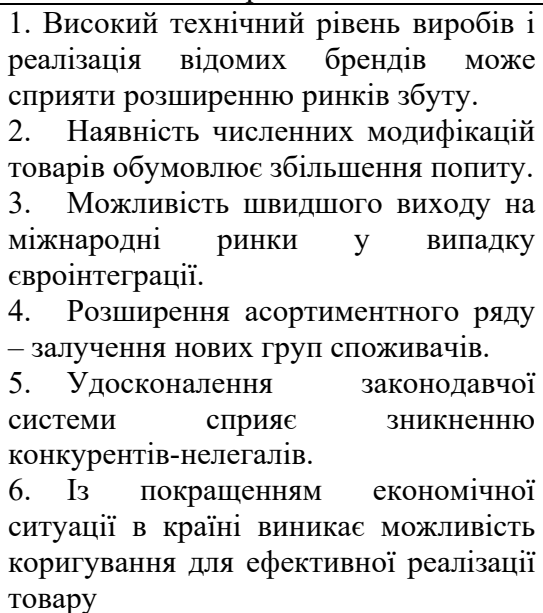 & $\begin{array}{l}\text { 1. Недостатній темп інновацій у системі } \\
\text { менеджменту уповільнює реагування на } \\
\text { потреби та запити споживачів. } \\
\text { 2. Неможливість прискореного розширення } \\
\text { асортименту товарів через безпосередню } \\
\text { залежність від компаній-постачальників. } \\
\text { 3. Недостатність заходів із популяризації } \\
\text { компанії серед клієнтів }\end{array}$ \\
\hline Загрози & $\begin{array}{l}\text { 1. Поява сильних конкурентів у } \\
\text { зв’язку з євроінтеграцією і виходом на } \\
\text { міжнародний ринок, які загрожують } \\
\text { втраті лідируючої позиції. } \\
2 \text { у випадку демографічних змін } \\
\text { можлива зміна цільових гру } \\
\text { споживачів }\end{array}$ & $\begin{array}{l}\text { 1. Втрата споживачів через політичну та } \\
\text { економічну нестабільність економіки і } \\
\text { різкі зміни грошових курсів. } \\
\text { 2. Витіснення компанії сильнішими } \\
\text { конкурентами через кризову ситуацію в } \\
\text { країні під час виходу на міжнародну } \\
\text { apeну }\end{array}$ \\
\hline
\end{tabular}

Підсумовуючи результати SWOT-аналізу, можна визначити, що через нестабільну ситуацію на даний час у нашій країні компанія «АЛЛО» не має можливості із високим ступенем вірогідності спрогнозувати нові стратегії виходу на зовнішні ринки. Євроінтеграційні процеси в Україні спонукають компанії-лідери в усіх сферах економіки до прискіпливішого вивчення світового досвіду ведення бізнесу. Завдяки саме інноваційним заходам у системі менеджменту і формуванні стратегічних планів, орієнтованих на внутрішній ринок, компанія «АЛЛО» на сьогодні займає лідируюче місце у своєму сегменті ринку, незважаючи на непросту ситуацію в економіці.

Компанія має потенціал і потребу в застосуванні розширеного спектра інновацій, які посилять іiї взаємозв'язок із клієнтами та продемонструє корисність для суспільства в цілому.

У компанії «АЛЛО», як уже було зазначено вище, застосовують філіальну систему менеджменту. Кожен філіальний регіон розділено на окремі філіали, а філіали, у свою чергу, на підрозділи. Щоб проаналізувати ефективність системи менеджменту, розглянемо критерії оцінки діяльності підрозділів, які застосовують для досягнення стратегічних цілей компанії в цілому. Для цього виділимо загальний показник розрахунку ефективності діяльності кожного підрозділу коефіцієнт виконання плану. За допомогою даного показника аналізують рентабельність роботи підрозділів, він слугує чинником для формування планів подальшої діяльності. 
Коефіцієнт виконання плану обчислюють для окремих груп. Загальний коефіцієнт виконання плану розраховують за формулою

$$
\kappa_{\text {ви }}=\frac{Д_{\text {факт }}}{Д_{\text {план }}} 0,5+\frac{A_{\text {факт }}}{A_{\text {план }}} 0,15+\frac{H_{\text {факт }}}{H_{\text {план }}} 0,15+\frac{C m_{\text {факт }}}{C m_{\text {план }}} 0,1+\frac{T_{\text {факт }}}{T_{\text {план }}} 0,1,
$$

де $\frac{Д_{\text {факm }}}{Д_{\text {пан }}}-$ відношення фактичної виручки (грн) до планової виручки від продажу пристроїв (грн); $\frac{A_{\text {факт }}}{A_{\text {пан }}}-$ відношення фактичної виручки (грн) до планової виручки від продажу аксесуарів (грн); $\frac{H_{\text {факт }}}{H_{\text {пиан }}}-$ відношення фактичної виручки (грн) до планової виручки від продажу додаткових послуг (грн); $\frac{C m_{\text {факm }}}{C m_{\text {nаaн }}}-$ відношення фактичної суми продаж до планової суми продаж страховок + страховки банків (грн); $\frac{T_{\text {факт }}}{T_{\text {план }}}-$ відношення фактичної кількості (шт.) до планової кількості продукції операторів (шт.).

Під час розрахунку коефіцієнта виконання плану відсоток виконання плану округлюють до 1-го знака після коми. Для рентабельної і ефективної роботи підрозділу цей коефіцієнт повинен становити понад $80 \%$. У разі невиконання даного показника на всіх співробітників підрозділу накладають штраф.

Проаналізуємо розглядуваний показник одного з підрозділів за період із 1 по 31 січня 2016 р. (табл. 4).

Таблиця 4

Результати ефективності діяльності підрозділу компанії «АЛЛО» за січень 2016 р.

\begin{tabular}{|c|c|c|c|c|}
\hline Фінансовий показник & План, грн & Факт, грн & Факт, \% & \multirow{2}{*}{ КВП } \\
\hline $\begin{array}{c}\text { Виручка від реалізації } \\
\text { пристроїв, грн. : }\end{array}$ & 498509,45 & 876801,97 & 175,88 & \multirow{2}{*}{168,91} \\
\hline терміналів & 448954,02 & 770517,18 & 171,62 \\
\hline планшетів & 49555,43 & 106284,79 & 214,48 \\
\hline категорія «+» & - & 12880,01 & - \\
\hline Страховки загалом, грн : & 8554,06 & 15110,16 & 176,64 \\
\hline банківські & 2353,18 & 822,10 & 34,94 & \\
\hline $\begin{array}{c}\text { Виручка від реалізації } \\
\text { аксесуарів, грн }\end{array}$ & 6200,88 & 14288,06 & 141,33 & \\
\hline $\begin{array}{c}\text { Виручка від реалізації } \\
\text { додаткових послуг, грн }\end{array}$ & 375038,56 & 120183,21 & 164,59 & \\
\hline $\begin{array}{c}\text { Кількість продукції } \\
\text { операторів, шт. }\end{array}$ & 496,34 & 81884,74 & 174,01 \\
\hline
\end{tabular}

* Розраховано на основі внутрішньої звітності підрозділу Х компанії «АЛЛО».

Опрацювавши результати ефективності діяльності підрозділу за цей період, можна зробити висновок, що підрозділ перевиконав планові показники за місяць на $68,91 \%$, що свідчить про рентабельність і ефективну роботу співробітників. У такому разі компанія у наступному місяці збільшить планові показники. Цей процес можна трактувати як із позитивного, так і негативного боку. Позитивним фактором $\epsilon$ те, що перевиконання плану свідчить про можливість підрозділу збільшувати валові показники й отримувати більші прибутки. Негативним - те, що при цьому не враховують ситуацію з попитом у різні місяці, що може призвести до регресивної зміни показників. Детальніше відображення діяльності підрозділу 
компанії за допомогою показника виконання плану за 2015 р. подано у вигляді діаграми (рис. 1).

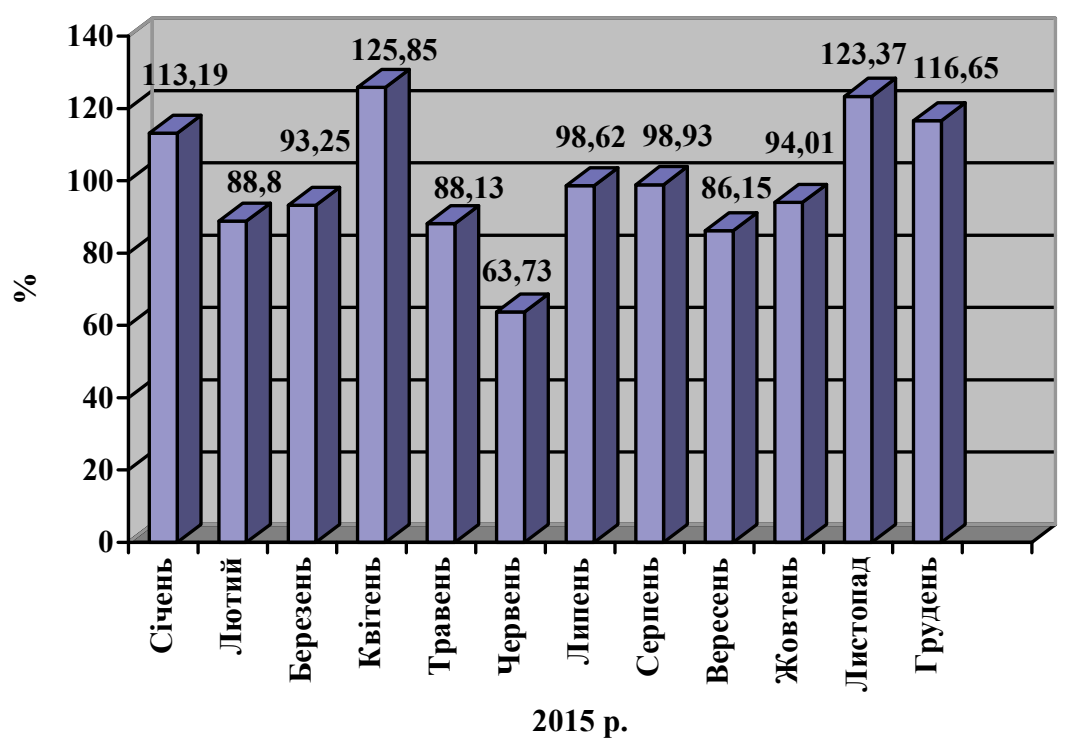

Рис. 1. Зміна коефіціснта виконання плану за період із 1 січня по 31 грудня 2015 р.

Діаграма підтверджує гіпотезу про те, що ефективність і рентабельність діяльності підрозділу залежать від сезонності, економічних факторів, ситуації в країні та інших факторів.

Аналіз діяльності компанії, її перспектив і завдань розвитку свідчить про необхідність проведення інновацій, які забезпечать стратегічну стійкість і конкурентоспроможність компанії в мінливому конкурентному середовищі.

Сьогодні існує багато класифікацій інновацій, що враховують специфіку їх появи та застосування [11]. Й. Шумпетер - перший економіст, який увів поняття «нововведення» та «інновація», за предметним змістом виділяв чотири види нововведень: 1) продуктові, спрямовані на виробництво й використання кінцевих типів виробів - засобів виробництва і предметів споживання; 2) технологічні, спрямовані на створення й застосування нових технологічних процесів для виробництва кінцевих видів виробів (продукції); 3) соціальні, суттю яких $\epsilon$ створення й застосування нових економічних, організаційних та інших механізмів, що забезпечують функціонування основних структурних ланок; 4) комплексні органічне поєднання кількох або всіх перелічених вище видів.

У процесі спілкування консультантів зі споживачами виявлено необізнаність останніх у програмних продуктах, установлюваних на пристрої, можливостях виконання завдань пристроями, які реалізує компанія. Тому пропонуємо розширити програму лояльності для клієнтів за допомогою соціальних інновацій: проведення безкоштовних ознайомчих лекцій упродовж 30 хв для різних вікових груп споживачів із заздалегідь визначеною тематикою у приміщеннях компанії; проведення безкоштовних 30-хвилинних лекцій, теми яких визначили самі споживачі; проведення даних лекцій у навчальних закладах. Крім того, потребують уваги соціальні інновації у вигляді благодійних акцій для незахищених верств населення, обдарованої молоді та ін. 
Розробка системи менеджменту організації дуже індивідуальна, тому слід враховувати специфіку діяльності організації. Аналіз наукової та нормативної документації щодо суті, завдань та очікуваних результатів від створення системи менеджменту організації дозволив авторам запропонувати загальну схему функціонування системи менеджменту організації (підприємства) (рис. 2).

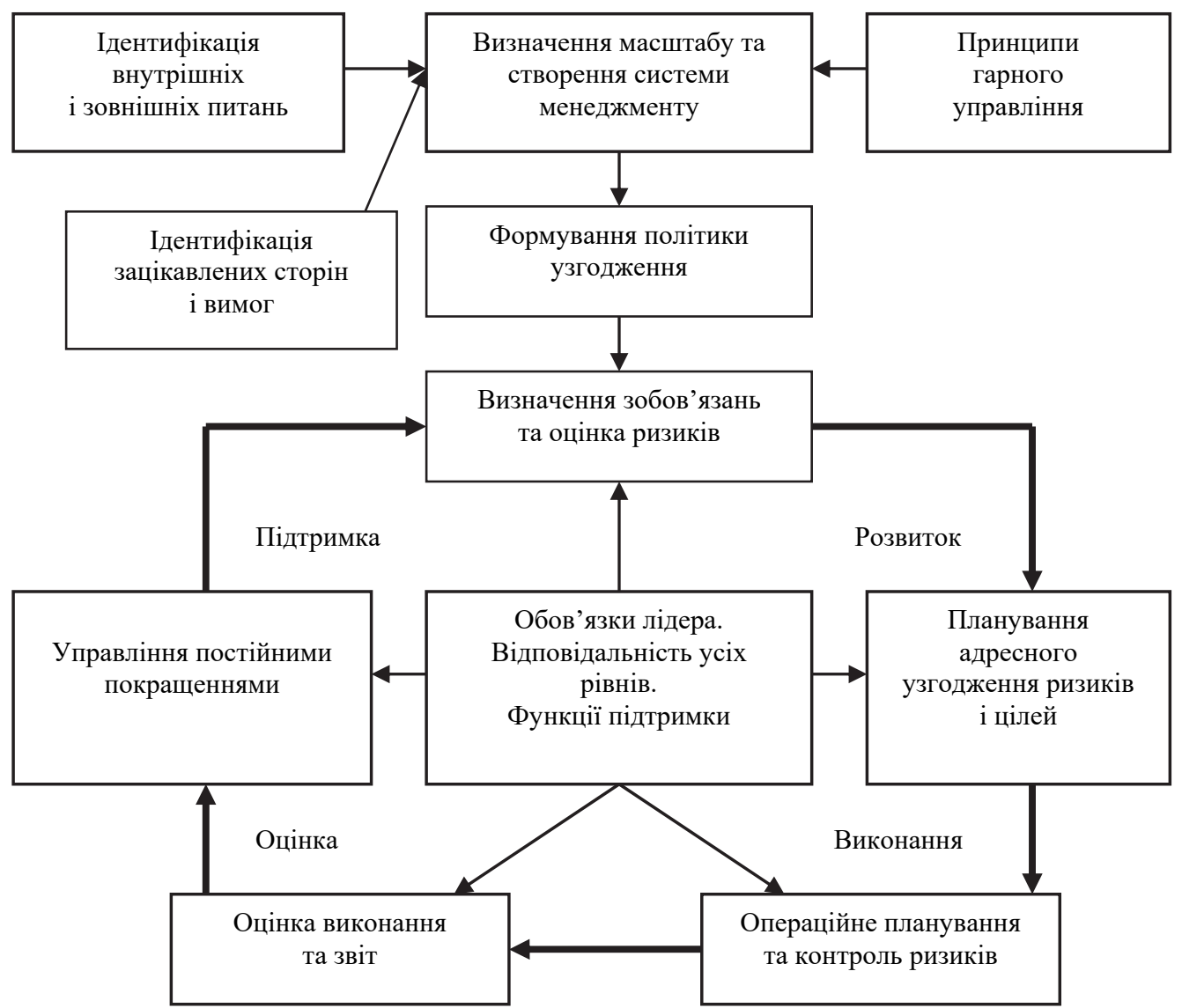

Рис. 2. Загальна схема функціонування системи менеджменту «вищого рівня» організації (підприсмства)

Крім того, авторами були виділені суттєві якісні характеристики ефективної системи менеджменту організащіі:

- отримання найвищих результатів серед конкурентів;

- можливість кардинально змінити своє життя;

- робота, що генерує радісні (позитивні) відчуття;

- створення власної опори організації;

- праця - це любов, яка видима.

Отже, на наш погляд, система менеджменту організації - це система, яка відображає вищу стадію розвитку організації та розкриває іiі вищу суть, формує відповідальність, забезпечує прості рішення організації в активному та конкурентному бізнес-середовищі, створює форми за допомогою думок $\mathrm{i}$ завершений цикл управління. 
Висновки. Аналіз діяльності підрозділу компанії «АЛЛО» і сучасних підходів до створення та впровадження системи менеджменту організації дозволив розробити загальну схема функціонування системи менеджменту компанії «АЛЛО» «вищого рівня». Крім того, проведений аналіз дозволив чітко сформулювати заходи iз підвищення конкурентоспроможності та стратегічної стійкості компанії «АЛЛО»: 1) врахування сезонних фактори попиту на товари; 2) упровадження нових ідей (соціальних інновацій) залучення клієнтів, які відрізняються від компаній-конкурентів; 3) упровадження в систему менеджменту більше мотиваційних програм для заохочення співробітників; 4) упровадження інноваційних освітніх заходів програми лояльності клієнтів, що підвищують цінність послуг компанії як для індивідуумів, так і суспільства в цілому; 5) розширення асортименту магазинів для залучення нових клієнтів і підвищення прибутку.

Наукова новизна дослідження полягає у визначенні сучасних вимог споживачів до компаній-рітейлерів побутової техніки, обгрунтуванні розширення обсягу соціальних інновацій в умовах нестабільного зовнішнього середовища та активізації євроінтеграційних процесів в Україні, формулюванні суттєвих якісних характеристик ефективної системи менеджменту організації, визначенні поняття «системи менеджменту організації» та розробці оптимальної загальної схеми функціонування системи менеджменту («вищого рівня») організації із урахуванням процесів створення та покращення ії бізнесу.

Практична значущість дослідження полягає у формуванні чіткої схеми реалізації системи менеджменту («вищого рівня») компанії, яка реалізує функції розвитку, виконання, оцінки, підтримки для організації будь-якого типу, у тому числі й для компанії-рітейлера побутової техніки; конкретних заходах - соціальних інноваціях, які дозволять компанії бути більш привабливою для різних груп споживачів і забезпечити досягнення своїх стратегічних цілей.

Подальшого дослідження потребують розробка нормативних документів, що стосуються системи менеджменту організації в межах загальної схеми системи менеджменту («вищого рівня») організації, розробки різноманітних інновацій, які враховують регіональний аспект розміщення компанії, швидкого впровадження позитивного досвіду міжнародних компаній даного типу.

\section{Бібліографічні посилання}

1. Бараненко, С. П. Стратегическая устойчивость предприятия [Текст] / С.П. Бараненко, В.В. Шеметов. - М.: ЗАО Центрполиграф, 2004. - 493 с.

2. Джур, О.Є. Конкурентний потенціал підприємств космічної галузі: теоретико-методологічний аспект [Текст] / О.С. Джур // Зб. наук. пр. Черкас. держ. технол. ун-ту. Сер.: Екон. науки. - 2013. - Вип. 35, ч. II. - С.125-130.

3. Теоретичні та прикладні аспекти підвищення конкурентоспроможності підприємств [Текст]: колективна монографія у 4 т. / за ред. О.А. Паршиної. Д.: Герда, 2013. - Т.4. - 325 c.

4. Mechanism of Sustainable Development of Economic Systems Formation [Text]: collective monograph. - Nürnberg: Verlag SWG imex Gmbh, 2014. - Vol. 2. - 392 p.

5. Кальніцька, М. О. Вплив організаційної культури на інноваційний потенціал підприємства [Текст] / М. О. Кальніцька // Вісник Дніпропетровського університету. Серія: Менеджмент інновацій. - 2015. - Вип. 5. - С. 60 - 71. 
6. Чейз, Р. Б. Производственный и операционный менеджмент [Текст] / Р.Б. Чейз, Ф.Р. Джейкобз, Н.Дж. Аквилано; пер. с англ. - 10-е изд. - М.: ООО «И.Д. Вильямс», 2007. - 1184 с.

7. Фатхутдинов, Р. А. Организация производства [Текст]: учебник / Р. А. Фатхутдинов. - М.: ИНФРА-М, 2001. - 672 с.

8. Organizational Structure [Electronic resource]. - Access mode: https://www.mgtsystems.com/organizational-structure. - Title fom the screen.

9. Офіційний сайт International Organization for Standardization [Електронний pecypc]. - Режим доступу: www.iso.org. - Заголовок з екрана.

10. Кризис в стандартизации систем менеджмента. Причины. Пути выхода [Електронный pecypc]. - Access mode: http://www.vniis.ru/file/bulletin1/DEFAULT/org.stretto.plugins.bulletin.core.Article/file/1462. - Заголовок з екрана.

11. InnoSupportTransfer - Supporting Innovations in SME [Electonic resource]. Режим доступу: http://www.innosupport.net/uploads/media/1_Innovation_issues.pdf. Title fom the screen.

\section{Bibliographic references}

1. Baranenko, S. P. Stratehycheskaia ustoichyvost predpryiatyia / S. P. Baranenko, V. V. Shemetov. M.: ZAO Tsentrpolyhraf, 2004. - $493 \mathrm{~s}$.

2. Dzhur, O. Ye. Konkurentnyi potentsial pidpryiemstv kosmichnoi haluzi: teoretykometodolohichnyi aspekt / O. Ye. Dzhur // Zb. nauk. pr. Cherkas. derzh. tekhnol. un-tu. Ser.: Ekon. nauky. 2013. - Vyp. 35, ch. II. - S.125 - 130.

3. Teoretychni ta prykladni aspekty pidvyshchennia konkurentospromozhnosti pidpryiemstv : kolektyvna monohrafiia u 4 t. / za red. O.A. Parshynoi. - D.: Herda, 2013. - T.4. - 325 s.

4. Mechanism of Sustainable Development of Economic Systems Formation [Text]: collective monograph. - Nürnberg: Verlag SWG imex Gmbh, 2014. - Vol. 2. - 392 p.

5. Kalnitska, M. O. Vplyv orhanizatsiinoi kultury na innovatsinyi potentsial pidpryiemstva / M. O. Kalnitska // Vìsnik Dnìpropetrovs'kogo universitetu. Seriâ: Menedžment ìnnovacìj. - 2015. - Vyp. 5. S. $60-71$.

6. Cheiz, R. B. Proyzvodstvennyi y operatsyonnyi menedzhment / R.B. Cheiz, F.R. Dzheikobz, N.Dzh. Akvylano; per. s anhl. - 10-e yzd. - M.: OOO «Y.D. Vyliams», 2007. - 1184 s.

7. Fatkhutdynov, R. A. Orhanyzatsyia proyzvodstva : uchebnyk / R. A. Fatkhutdynov. - M.: YNFRAM, 2001. $-672 \mathrm{~s}$.

8. Organizational Structure [Electronic resource]. - Access mode: https://www.mgtsystems.com/organizational-structure. - Title fom the screen.

9. Ofitsiinyi sait International Organization for Standardization [Electronic resource]. - Access mode: www.iso.org.

10. Kryzys v standartyzatsyy system menedzhmenta. Prychyny. Puty vykhoda [Electronic resource]. - Access mode: http://www.vniis.ru/file/bulletin-1/DEFAULT/org.stretto.plugins.bulletin.core.Article/ file/ 1462 .

11. InnoSupportTransfer - Supporting Innovations in SME [Electonic resource]. - Access mode: http://www.innosupport.net/uploads/media/1_Innovation_issues.pdf. - Title fom the screen.

Надійшла до редколегії 20.02.2016 